Ethiopian Journal of Environmental Studies \& Management 9(3): 339 - 353, 2016. ISSN:1998-0507 doi: http://dx.doi.org/10.4314/ejesm.v9i3.8

Submitted: January 25, 2016 Accepted: May 12, 2016

\title{
IMPACT OF INDUSTRIAL CASSAVA EFFLUENT DISCHARGE ON THE WATER QUALITY OF OGBESE RIVER, AYEDE-OGBESE, ONDO STATE, NIGERIA
}

\author{
*OKOYA, A.A., OYAWALE, F.E., OFOEZIE, I.E., AND AKINYELE, A.B. \\ Institute of Ecology and Environmental Studies, Obafemi Awolowo University, Ile - Ife, \\ Nigeria
}

\begin{abstract}
Impacts of cassava effluent discharge on physicochemical parameters of water quality were assessed using standard procedure. Results showed TDS ranged (108.00 $\pm 28.2-$ $110.50 \pm 27.5 \mathrm{mg} / \mathrm{L}), 123.50 \pm 31.82-310.50 \pm 184.56 \mathrm{mg} / \mathrm{L})$ and (114.00 $\pm 31.11-115.50$ $\pm 30.41 \mathrm{mg} / \mathrm{L})$ for UWS, DPWS and DWS respectively. TSS in the effluent samples were $1287.50 \pm 137.89 \mathrm{mg} / \mathrm{L}$ and $19942.00 \pm 2791.08 \mathrm{mg} / \mathrm{L}$ during wet season and 1925.00 $\pm 0.00,21942.00 \pm 0.00 \mathrm{mg} / \mathrm{L}$ in dry season respectively. Highest BOD $(61.5 \pm 6.36 \mathrm{mg} / \mathrm{L})$ was at discharge point during wet season and lowest $(0.35 \pm 0.07 \mathrm{mg} / \mathrm{L})$ was downstream during dry season. In wet season, the BOD ranged $(2.00 \pm 0.5-3.20 \pm 1.13 \mathrm{mg} / \mathrm{L})$ upstream was lower relative to downstream range $(26.00 \pm 5.66-36.00 \pm 21.21 \mathrm{mg} / \mathrm{L})$. $\mathrm{pH}$ of water ranged (7.43 $\pm 0.46-7.85 \pm 0.78)$ and $(6.55 \pm 0.78-7.05 \pm 0.21)$ upstream and downstream respectively during wet season while $\mathrm{pH}$ ranged (7.15 $\pm 0.21-7.35 \pm 0.21$ ) and $6.70 \pm 0.00-$ $6.90 \pm 0.00)$ upstream and downstream respectively in dry season. At discharge points $\mathrm{pH}$ ranged $(5.90 \pm 0.00-6.50 \pm 0.42)$. Electrical conductivity (E.C.) in wet season has lowest value $191.50 \pm 54.45-192.50 \pm 50.20 \mu \mathrm{Scm}$ upstream and also lowest compared with all locations in dry season. Acidity of water ranged (30.00 $\pm 8.49-45.00 \pm 26.87,15.00 \pm 1.41-16.00 \pm 2.83$ and $80.00 \pm 8.49-4,320.00 \pm 4.24 \mathrm{mg} / \mathrm{L}$ ) respectively for downstream, upstream and discharge point in wet season. However range of acidity values in dry season were (30.00 $\pm 0.00-43.00 \pm 1.41$, $20.00 \pm 70.00-32.50 \pm 0.71$ and $47.50 \pm 13.44-5750.00 \pm 70.71 \mathrm{mg} / \mathrm{L}$ ) for downstream, upstream and discharge point respectively. Results indicated that water quality of downstream was impaired compared to upstream and season dependent, suggesting significant pollution from cassava effluent discharges. The effluent instilled unsightly, nauseating and undesirable effects on biotic community and rendered water useless for any domestic usage. Continuous monitoring of Ogbese River is imperative for future sustainability of the river.
\end{abstract}

Key Words: Water quality, Effluent, Physiochemical parameters, Permissible limit

\section{Introduction}

Pollution of water body in Nigeria occurs both in rural and urban areas (Awoyemi et al., 2014). Most rural area dwellers depend on river and stream water for drinking and these rivers are mostly polluted by organic substances. The organic substances pollution came from upstream user who may as well use water for some agricultural and industry

*Corresponding Author: Okoya, A.A.

Email: ronkeokoya@yahoo.com 
Impact of Industrial Cassava Effluent Discharge on the Water Quality.................KOYA et al.

related activities. Urban streams and rivers are characterized by the effects of urbanization on aquatic/stream ecosystems which are complex, with many physical, chemical and biological consequences (Suren, 2000). The implication of the anthropogenic activities along streams and rivers in the world is the alteration of the quality and ecological status of the receiving water body (Arimoro 2009; Arimoro and Ikomi 2008; Akpan 2004).

Like other human activities that have impact on the environment, industrialization often results in pollution and degradation. It carries inevitable costs and problems in terms of pollution and general degradation of the natural environment (Thomas et al., 1991, FEPA 1991). Owing to the increase in industrialization and population explosion, the water demand has increased. Also, a considerable part of this scares quantity of water is polluted by sewage, industrial wastes and a wide array of synthetic chemical (Adewoye, 2013).

The cassava (Manihot esculenta Crantz) is a woody shrub of Euphorbiaceae family. It is extensively cultivated as annual crop in tropical and subtropical regions of the world for its enable starchy tuberous root, a major source of carbohydrates. It is the third largest source of carbohydrates for human food in the world with Africa being its largest center of production (Claude and Denis, 1990). Cassava processing, especially in areas where the industry is highly concentrated, is regarded as polluting and a burden on natural resources. By its nature, cassava processing for starch extraction produces large amounts of effluent high in organic content. If untreated this may be displayed in the form of stagnant effluent ponds from which strong odours emanate. Other forms of processing, despite not requiring water, generate very visible dust waste. As a consequence of the visual display of pollution, cassava is often perceived by local populations as contributing significantly to environmental damage and water deficit. Yet, despite this notion, supported mainly by the visual display of pollution, few systematic impact studies have been conducted.

Annual cassava production in Africa is about 84 million tonnes, with about one third of this from Nigeria. Cassava is primarily produced by small-scale farmers and processed at the family- or village-level. Despite the small scale of operation, cassava production in Africa is highly commercialized, with as much as $45 \%$ of the total output marketed (Nweke et al., 1992). A great diversity of products is derived from cassava. Most farmers in Ayede-Ogbese Ondo State engage in the cultivation of Cassava for starch production and food consumption. Cassava is mostly produced by smallscale farmers on marginal soils and fragile environments in Africa, Asia and Latin America and the Caribbean, where animal manure and chemical fertilizers are not commonly applied to cassava crop (FAO 2004).

The effect of cassava effluent on Okada natural water was carried out by Ehiagbonare et al. (2009). The effect of cassava effluent discharge on the physico-chemical properties of Ayede Ogbese River water has not been investigated thereby necessitating the present study. 


\section{Materials and Methods}

Study Area

Samples were collected from Ogbese River in Ayede Ogbese town, Ondo State.The town lies within latitude $07^{\circ} 15^{\prime} 36.1^{\prime \prime}$ and longitude $005^{\circ} 22^{\prime} 47.7 \mathrm{E}^{\prime \prime}$ (Figure 1).

\section{Sampling Points}

Water samples (40) were collected from ten sampling points, four upstream (Uws), two at the discharge points (Dpws), four downstream (Dws) while four effluent samples were collected at the effluent channel (EDS) for two months each in the wet and the dry season (Figure 2).

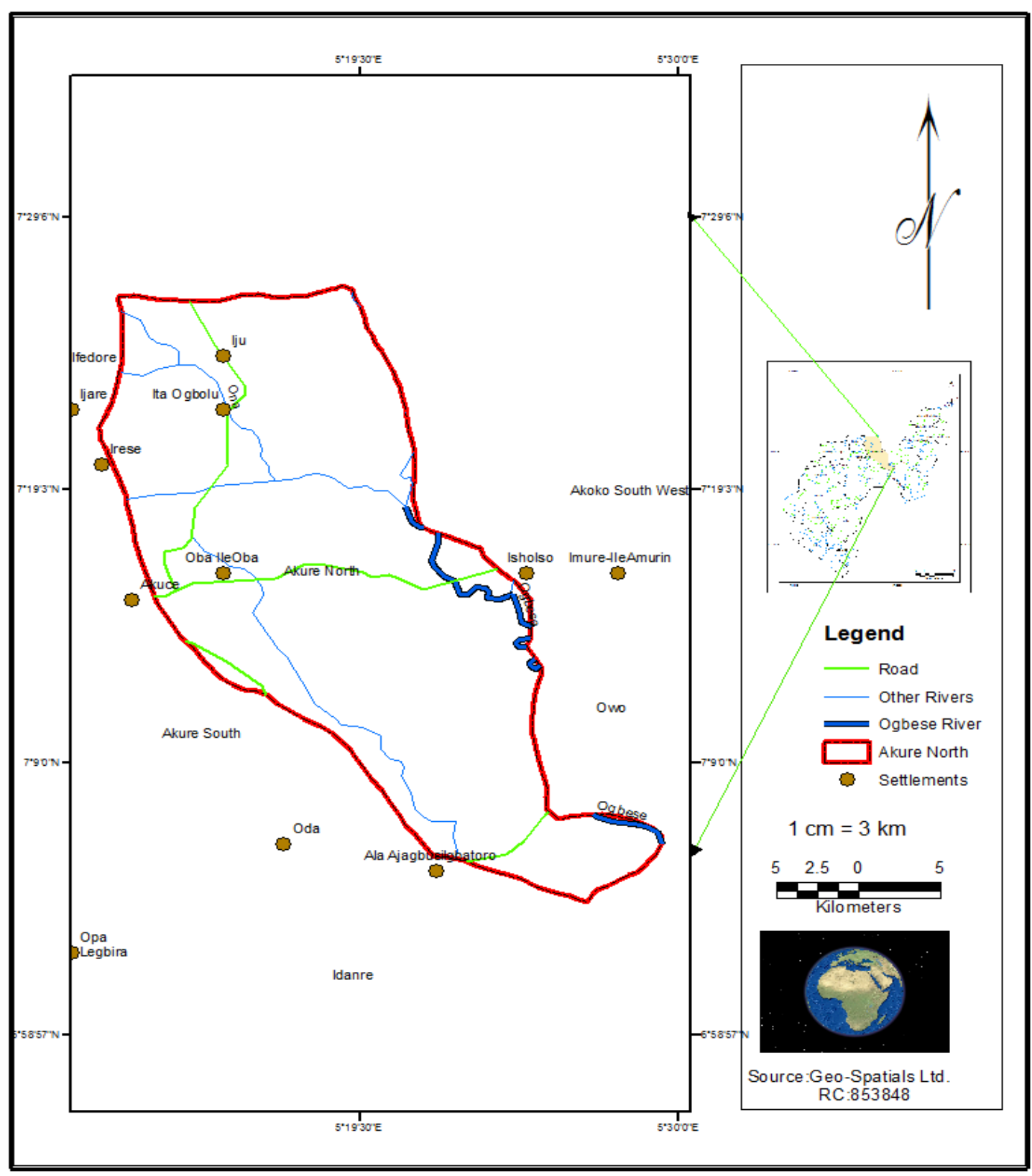

Figure 1: Map showing the location of Ogbese River in Ondo State 


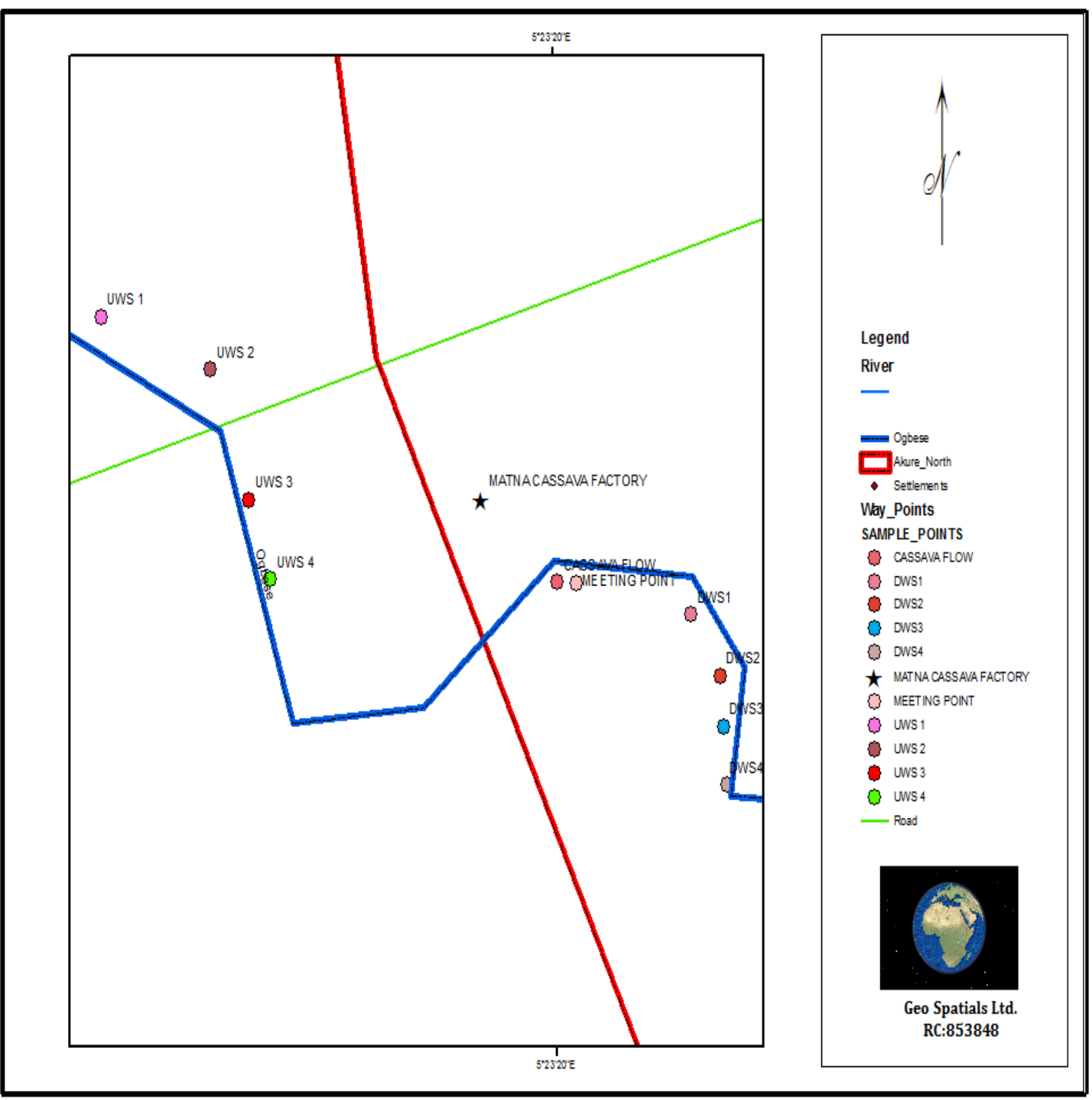

Figure 2: Map showing the sampling locations along the river

\section{Sample Collection and Analysis}

The samples (water and effluent samples) were collected in clean polythene bottles using standard methods and labeled. Depth and transparency were measured on the field using secchi disc. Samples for dissolved oxygen (DO) and biological oxygen demand $\left(\mathrm{BOD}_{5}\right)$ were collected according to standard. Dissolved oxygen samples were fixed on the field immediately after collection using Winkler's reagents and were determined by iodometric titration. Samples for biological oxygen demand (BOD) were kept in a dark cupboard at room temperature for five days incubation before being determined for dissolved oxygen. Water temperature at the time of sampling was determined on the field. Water samples for other chemical analysis were collected and transported to the laboratory for analyses. All the parameters were determined using standard methods (APHA, 1995) 


\section{Statistical Analysis}

All analysis was performed using SPSS software (version 16.0).Statistical procedures used include Scheffe, analysis of variance (ANOVA) and correlation. Relationships between metals and other physico-chemical parameters were determined by bivariate correlation using the Pearson coefficient in a two-tailed test $(\alpha=0.01$ and 0.05$)$.

\section{Results and Discussion}

\section{Physico-chemical Parameters of} Effluent

Table 1 showed the results of the physico-chemical analysis of cassava effluent before being discharged into the river. The effluent temperature depends on the process of production in the factory; the highest temperature was measured in the effluent samples during the dry season. The temperature values in the effluents at both seasons were within the permissible limits $\left(40^{\circ} \mathrm{C}\right)$ of National Environmental Quality Standards (NEQS) (NEQS, 2000) for municipal and industrial Effluents.

BOD measures the biodegradable materials in water (Manahan, 1994). The BOD of the effluent at both seasons were above the NEQS. Therefore high BOD in the effluent sample is an indication of the presence of high biodegradable materials. Cassava is generally high in organic carbon and this may have contributed to the high level of Total organic carbon in the effluent.
Comparing the TDS with the NEQS (3500), the values are within the permissible limit, effluent with high TDS may increase salinity when discharged into irrigation water. The TSS at both seasons are very high compared to the NEQS (150), Cassava processing effluent contains solid particles, the results suggested that these effluents may cause handling problem, if directly applied to agricultural field for irrigation or if discharged into surface water, it will be harmful for the aquatic life. These results agreed with the findings of Tariq et al, (2006) who reported a TSS range from 125 to $198 \mathrm{mg} / \mathrm{L}$ which is thus evident that waste water of all the industries had high TSS and were above the permissible limits of NEQS.

The $\mathrm{pH}$ of the effluent was below the permissible limit (6-10) and may adversely affect the aquatic life due to its acidic nature. These results are in line with the findings of Khan and Noor (2002) in the investigation of pollutants in wastewater of Hayatabad industrial estate Peshawar. The $\mathrm{pH}$ of the waste water was very low as compared with the standard $\mathrm{pH}$ of 6-10.

Electrical conductivity (EC) is a function of total dissolved solids known as ions concentration; all the EC values for the effluents were above the safe limits (NEQS $500 \mu \mathrm{Scm}-1$ ) indicating the presence of high amount of dissolved inorganic substances. 
Table 1: Physicochemical Characteristics of Cassava Effluents in Comparison with the National Environmental Quality Standard (NEQS) For Municipal and Industrial Liquid Effluents

\begin{tabular}{|c|c|c|c|}
\hline Parameters & Wet Season & Dry Season & NEQS \\
\hline $\mathrm{DO}(\mathrm{mg} / \mathrm{L})$ & ND & ND & NA \\
\hline $\mathrm{BOD}(\mathrm{mg} / \mathrm{L})$ & $84.00 \pm 8.49$ & $23.50 \pm 0.71$ & 80 \\
\hline TOC(mg/L) & $28.32 \pm 6.91$ & $51.67 \pm 0.02$ & 30 \\
\hline Temperature $\left({ }^{\circ} \mathrm{c}\right)$ & $30.50 \pm 0.71$ & $29.50 \pm 0.71$ & 40 \\
\hline TDS(mg/L) & $1287.50 \pm 137.89$ & $1925.00 \pm 0.00$ & 3500 \\
\hline $\mathrm{TSS}(\mathrm{mg} / \mathrm{L})$ & $19942.41 \pm 2791.08$ & $21942.00 \pm 0.00$ & 150 \\
\hline Turbidity (NTU) & $317.25 \pm 0.00$ & $2682.44 \pm 0.00$ & 500 \\
\hline T. Colour (Pt-Co) & $1835.25 \pm 904.73$ & $1654.29 \pm 1901.28$ & NA \\
\hline Ap. Colour (Pt-Co) & $3146.71 \pm 0.00$ & $26988.95 \pm 0.00$ & NA \\
\hline Conductivity $(\mu \mathrm{Scm})$ & $2565.00 \pm 615.18$ & $3840.50 \pm 70.00$ & 500 \\
\hline $\operatorname{Acidity}(\mathrm{mg} / \mathrm{L})$ & $6540.00 \pm 2969.85$ & $39050.00 \pm 494.97$ & 20 \\
\hline $\mathrm{pH}$ & $5.85 \pm 0.07$ & $5.75 \pm 0.07$ & $6-10$ \\
\hline $\mathrm{Cl}^{-}(\mathrm{mg} / \mathrm{L})$ & $26.21 \pm 0.83$ & $67.21 \pm 0.32$ & NA \\
\hline $\mathrm{NO}_{3}^{-}(\mathrm{mg} / \mathrm{L})$ & $19.47 \pm 8.97$ & $17.00 \pm 0.01$ & NA \\
\hline $\mathrm{HCO}_{3}{ }^{-}(\mathrm{mg} / \mathrm{L})$ & ND & ND & NA \\
\hline $\mathrm{SO}_{4}^{-}(\mathrm{mg} / \mathrm{L})$ & $918.45 \pm 543.23$ & $26.00 \pm 0.71$ & NA \\
\hline Alkality (mg/L) & ND & ND & NA \\
\hline Hardness $(\mathrm{mg} / \mathrm{L}$ & $15212.40 \pm 9273.78$ & $773.34 \pm 65.30$ & NA \\
\hline
\end{tabular}

$\mathrm{NA}=$ not available, $\mathrm{ND}=$ not detected

\section{Physico-chemical Parameters of Water Samples}

The difference in temperature of the river water as shown in Figure 3 could be due to the high effluent temperature being released directly into the river. The result is supported by Tariq et al. (2006) who reported that high temperature in the effluents can cause thermal pollution due to the usage of water during steam production and cooling processes. Results revealed that all values were within the permissible limits in WHO standards. Temperature is an important indication of water quality with respect to survival of aquatic organisms (Tariq et al., 2006).

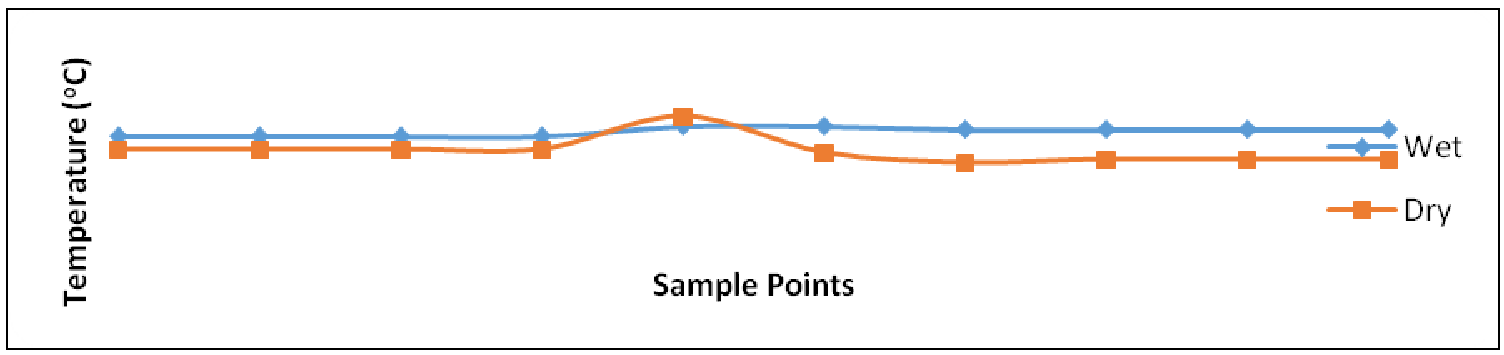

Figure 3: Temperature of river water in wet and dry seasons

The river water is naturally odourless right from its course as the odour value of the upstream water is 1 at both seasons (Figures 4 and 5) while that of the 
effluent is 5. This implies that it has a very strong odour with a negative impact on the river which has an unpleasant odour at the discharge point (Odour value $=4$ ) and downstream (Odour value $=5$ ). The odour being perceived from a long distance from the site is an indication of air pollution. The odour is stronger at these points during the dry season but reduces in the wet season. The reduction of odour in the wet season may be due to dilution of the river by rain water. This result is in line with research carried out by Ehiagbonare et al. (2009) on impact of cassava effluent on Okada natural water where it was found that from the point of discharge, odour could be perceived from a mean distance of $90.3 \mathrm{~m}$.

Changes in water depth (Figure 4) were mainly due to successive rainfall throughout all the months. There was a significant difference in water depth at different stations and this can be ascribed to the nature of the riverbed, which is uneven (Francis et al., 2008).

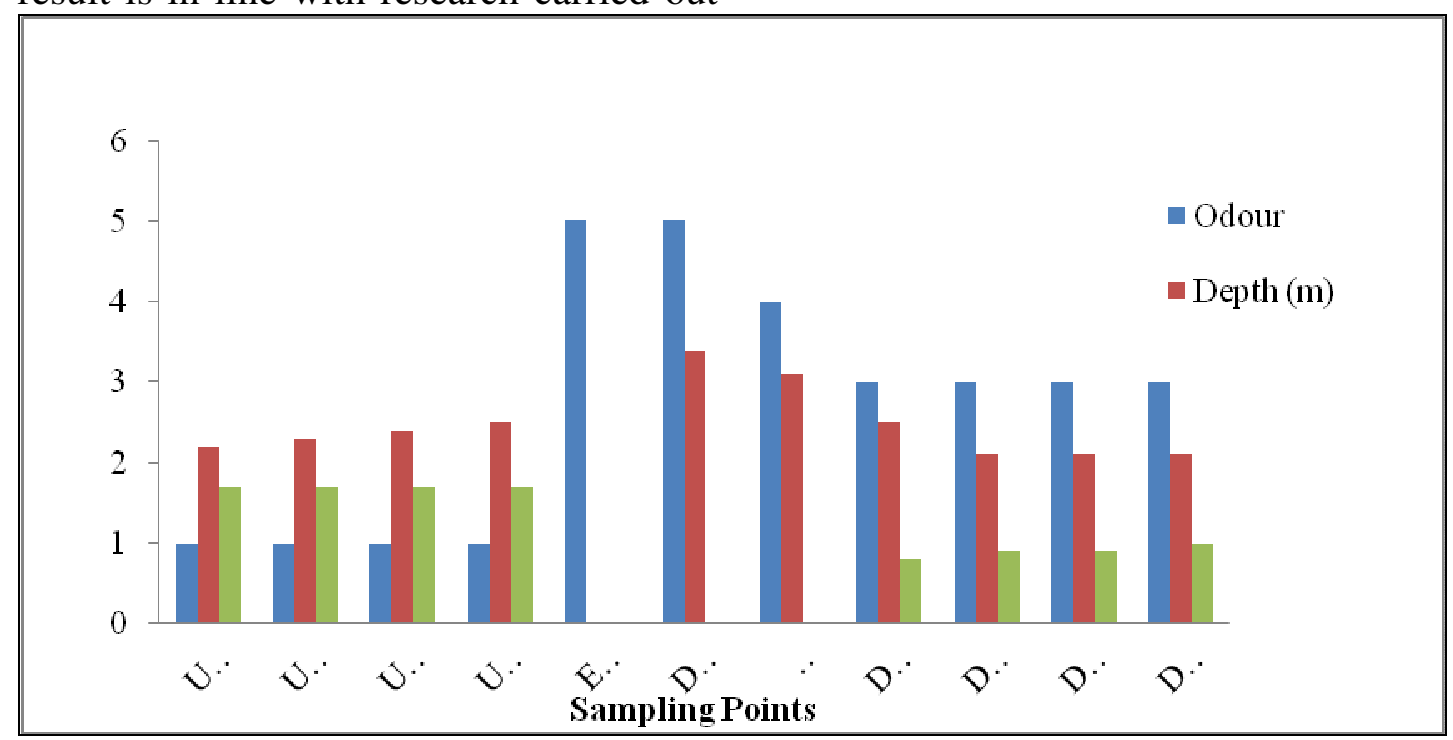

Figure 4: Odour, depth and transparency of river water during the wet season

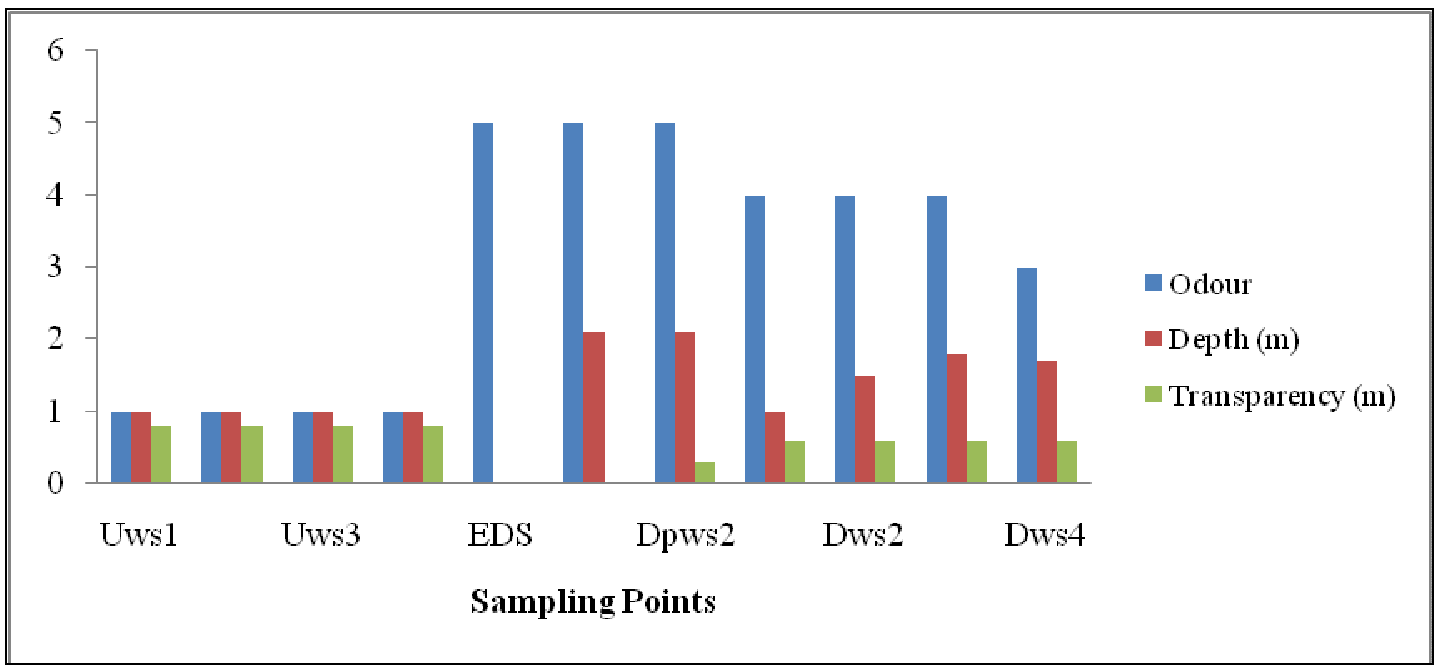

Figure 5: Odour, depth and transparency of river water during the dry season 
As for the water colour (Table 2), the values obtained during the wet season in all the sampling locations were higher than those obtained during dry season, this could be caused by the stirring up of the river water when rain falls while the higher values obtained downstream at both season could be due to the impact of the Cassava effluent. The values at the discharged points were generally high at both seasons. Colour of any water body is in relation to the background either the vegetation around or the reflection of the cloud or the water bed. Colour can be green, blue or light green. The colour of water tells us the contents of the water, it may have to do with the nutrient status of the water or the chemical compound present in the water (Department of Fisheries and Aquatic Sciences 2004).

Turbidity is a measure of the cloudiness of water (Ololade and Ajayi, 2009). The river was visibly coloured during wet season while the downstream water sample and the discharge point were coloured at both seasons (Table 2). The former attributed to run-off activities while the latter could be due to the effect of the discharged effluent but the values reduce in the rainy season, when the quantity of water flowing in the stream is increased during and after rainfall, the concentrations of contaminants may be significantly reduced. The values obtained from the effluent and all the water samples during the wet season were generally greater than the WHO recommended value (5 NTU) for drinking water. There is a clear impact of the effluent on the turbidity of the water following the result obtained during the dry season for there was an increase at the discharge point compared to the upstream value. The relatively high level could be attributed to the presence of decaying organic matter present in the cassava effluent, this agrees with the findings of Ololade and Ajayi (2009) on the contamination profile of major rivers along the highways in Ondo State. These increased levels are often associated with higher level of disease causing microorganisms such as viruses, parasites and some bacteria (US EPA 2004).

The TDS was highest at the discharge point at both seasons (Table 2). The values were higher in the dry season compared to the wet season; all values still lied within the FEPA standards in water. High level of TDS may increase the water salinity problem if discharged to irrigation water (Mahananda et al., 2010). The high TDS and TSS could be attributed to the components of the cassava effluent which required some oxygen for oxidation, causing low DO and high BOD and COD in the water body.

The result showed that the TSS was low in the upstream and increases downstream with the highest value at the discharge point (Table 2). Adewoye et al. (2005) and Nwaugo and Onyeagba, (2004) stated that concentrations of any given pollutant are highest at the point of discharge, the values of most of the parameters analyzed in this present study followed the same trend. As a result of the impact of the effluents, the environmental condition will not be conducive for aquatic life in the water. The presence of high level of TSS is an indication of the impact of the industrial effluents at a distance close to the point of discharge; moreso that the effluents were not pre-treated. The TSS at the discharge point and downstream were higher than FEPA permissible standard. High TSS can absorb heat from the sun and transfer same to the water body 
thereby raising the temperature of the water body (Muoghalu and Omocho 2000). Turbidity of water can be increased by TSS and this has the capacity to depress light penetration into a given body of water, thus negatively affecting the fish feeding habit and the growth of phytoplankton (Ehiagbonare $e t$ al., 2009).

Depending on the water temperature requirement for a particular aquatic species at various stages, the DO criteria values range from $5-95 \mathrm{mg} / \mathrm{L}$ for warm - water biota. Low DO which was obtained downstream when combined with the presence of toxic substance may lead to stress response in aquatic ecosystems because the toxicity of certain elements, such as $\mathrm{Zn}, \mathrm{Pb}$ and $\mathrm{Cd}$, is measured by low concentration of DO. DO in water is usually depleted if organic matters undergoing biological degradation are present (Ololade and Ajayi, 2009).

Biological oxygen demand (BOD) measures the biodegradable materials in water (Manahan, 1994). The BOD values were generally high downstream and at the discharge point during the rainy season (Table 4). The down-pour of rain during this time may also have contributed to this. However, the BOD values of the downstream samples during dry season was due to high level of pollution by organic substances in the Cassava effluent which may have used up most of the available oxygen present, these values are very high. This is in line with the findings of Ehiagbonare et al. (2009), in which it was discovered that the BOD obtained downstream was higher than the acceptable FEPA standard which implied that the water from the body receiving cassava effluent is not portable. High BOD in the water downstream suggested that the industrial effluents might have contributed some organic load to such water, which is potential threat to the quality of the water. 
Table 3: Levels of chemical parameters in water sample during dry and wet seasons

\begin{tabular}{|c|c|c|c|c|c|c|c|c|c|c|}
\hline & \multicolumn{2}{|c|}{$\mathrm{pH}$} & \multicolumn{2}{|c|}{ Conductivity $\left(\mu \mathrm{Scm}^{-1}\right)$} & \multicolumn{2}{|c|}{ Acidity $(\mathrm{mg} / \mathrm{L})$} & \multicolumn{2}{|c|}{ Alkalinity $(\mathrm{mg} / \mathrm{L})$} & \multicolumn{2}{|c|}{ Hardness (mg/L) } \\
\hline $\begin{array}{l}\text { Sampling } \\
\text { Points }\end{array}$ & Wet & Dry & Wet & Dry & Wet & Dry & Wet & Dry & Wet & Dry \\
\hline UWS1 & $7.70 \pm 0.57$ & $7.2 \pm 0.14$ & $191.50 \pm 54.45$ & $223.50 \pm 0.71$ & $15.00 \pm 1.41$ & $21.50 \pm 0.71$ & $62.00 \pm 14.14$ & $86.00 \pm 2.83$ & $53.23 \pm 15.63$ & $74.90 \pm 0.30$ \\
\hline UWS2 & $7.43 \pm 0.46$ & $7.20 \pm 0.14$ & $192.50 \pm 53.03$ & $223.50 \pm 0.71$ & $16.00 \pm 2.83$ & $32.50 \pm 0.71$ & $64.00 \pm 11.31$ & $86.50 \pm 0.71$ & $54.14 \pm 19.33$ & $72.88 \pm 3.29$ \\
\hline UWS3 & $7.45 \pm 0.49$ & $7.15 \pm 0.21$ & $191.50 \pm 54.45$ & $230.00 \pm 4.24$ & $15.00 \pm 1.41$ & $32.5 .00 \pm 0.71$ & $64.00 \pm 14.14$ & $86.00 \pm 0.00$ & $62.27 \pm 33.52$ & $72.89 \pm 3.34$ \\
\hline UWS4 & $7.85 \pm 0.78$ & $7.35 \pm 0.21$ & $192.50 \pm 50.20$ & $225.50 \pm 0.71$ & $15.00 \pm 1.41$ & $20.00 \pm 70.00$ & $64.00 \pm 11.31$ & $83.00 \pm 1.41$ & $60.49 \pm 33.49$ & $77.03 \pm 0.09$ \\
\hline DPWS1 & $6.55 \pm 0.78$ & $5.90 \pm 0.00$ & $483.00 \pm 216.37$ & $248.00 \pm 7.07$ & $4,320.00 \pm 4.24$ & $5750.00 \pm 70.71$ & $0.00 \pm 0.00$ & $0.00 \pm 0.00$ & $344.21 \pm 331.76$ & $525.11 \pm 29.50$ \\
\hline DPWS2 & $6.70 \pm 0.71$ & $6.50 \pm 0.42$ & $209.00 \pm 57.98$ & $224.00 \pm 0.00$ & $80.00 \pm 8.49$ & $47.50 \pm 13.44$ & $69.00 \pm 26.87$ & $48.50 \pm 14.85$ & $60.49 \pm 18.12$ & $76.59 \pm 0.52$ \\
\hline DWS1 & $6.95 \pm 0.21$ & $6.90 \pm 0.28$ & $204.50 \pm 61.52$ & $222.50 \pm 0.71$ & $30.00 \pm 8.49$ & $30.00 \pm 0.00$ & $71.00 \pm 24.04$ & $86.00 \pm 0.00$ & $56.82 \pm 15.60$ & $73.16 \pm 0.21$ \\
\hline DWS2 & $7.05 \pm 0.21$ & $6.80 \pm 0.00$ & $202.50 \pm 61.52$ & $222.00 \pm 0.00$ & $28.00 \pm 11.31$ & $43.00 \pm 1.41$ & $75.00 \pm 18.38$ & $84.50 \pm 0.71$ & $56.87 \pm 15.66$ & $75.00 \pm 2.33$ \\
\hline DWS3 & $7.10 \pm 0.57$ & $6.70 \pm 0.00$ & $204.50 \pm 64.35$ & $224.50 \pm 0.71$ & $45.00 \pm 26.87$ & $40.50 \pm 0.71$ & $69.00 \pm 21.21$ & $86.50 \pm 0.71$ & $56.84 \pm 15.63$ & $75.24 \pm 0.18$ \\
\hline DWS4 & $6.95 \pm 0.35$ & $6.90 \pm 0.00$ & $204.00 \pm 63.64$ & $223.50 \pm 0.00$ & $31.00 \pm 9.90$ & $37.00 \pm 1.41$ & $75.00 \pm 29.70$ & $0.00 \pm 0.00$ & $53.27 \pm 15.52$ & $77.00 \pm 0.18$ \\
\hline WHO & $6.5-9.5$ & $6.5-9.5$ & 20 & 20 & Nil & Nil & Nil & Nil & $100=200$ & $100-200$ \\
\hline
\end{tabular}


Impact of Industrial Cassava Effluent Discharge on the Water Quality.................KOYA et al.

Table 4: Concentrations of DO, BOD and TOC of river water samples in the dry and wet seasons

\begin{tabular}{|c|c|c|c|c|c|c|}
\hline \multirow[b]{2}{*}{ Sampling Points } & \multicolumn{2}{|l|}{$\mathrm{DO}(\mathrm{mg} / \mathrm{L})$} & \multicolumn{2}{|l|}{$\mathrm{BOD}(\mathrm{mg} / \mathrm{L})$} & \multicolumn{2}{|c|}{ TOC $(\mathrm{mg} / \mathrm{L})$} \\
\hline & Wet & Dry & Wet & Dry & Wet & Dry \\
\hline UWS1 & $5.00 \pm 1.41$ & $7.65 \pm 0.07$ & $2.20 \pm 0.28$ & $5.15 \pm 0.07$ & $0.67 \pm 0.06$ & $0.23 \pm 0.00$ \\
\hline UWS2 & $5.40 \pm 0.28$ & $7.70 \pm 0.14$ & $2.00 \pm 0.57$ & $4.00 \pm 0.00$ & $0.28 \pm 0.06$ & $1.98 \pm 0.00$ \\
\hline UWS3 & $5.20 \pm 0.57$ & $7.00 \pm 0.28$ & $2.00 \pm 0.00$ & $4.00 \pm 0.00$ & $1.19 \pm 0.38$ & $1.77 \pm 0.07$ \\
\hline UWS4 & $5.40 \pm 0.28$ & $6.90 \pm 0.14$ & $3.20 \pm 1.13$ & $3.60 \pm 0.00$ & $0.33 \pm 0.13$ & $0.24 \pm 0.01$ \\
\hline DPWS1 & $0.00 \pm 0.00$ & $0.00 \pm 0.00$ & $61.5 \pm 6.36$ & $19.00 \pm 1.41$ & $7.78 \pm 0.79$ & $0.67 \pm 0.02$ \\
\hline DPWS2 & $2.60 \pm 3.68$ & $2.30 \pm 2.69$ & $33.5 \pm 12.02$ & $3.45 \pm 4.45$ & $1.44 \pm 0.68$ & $1.98 \pm 0.00$ \\
\hline DWS1 & $3.40 \pm 2.55$ & $3.10 \pm 0.14$ & $30.50 \pm 7.78$ & $0.35 \pm 0.07$ & $1.23 \pm 1.41$ & $0.24 \pm 0.00$ \\
\hline DWS2 & $3.20 \pm 2.83$ & $3.45 \pm 0.07$ & $26.00 \pm 5.66$ & $0.40 \pm 0.14$ & $2.25 \pm 0.00$ & $1.73 \pm 0.01$ \\
\hline DWS3 & $3.25 \pm 2.76$ & $3.55 \pm 0.07$ & $29.00 \pm 9.90$ & $0.35 \pm 0.07$ & $1.98 \pm 0.01$ & $2.67 \pm 0.01$ \\
\hline DWS4 & $2.40 \pm 3.39$ & $3.55 \pm 0.07$ & $36.00 \pm 21.21$ & $0.75 \pm 0.07$ & $1.47 \pm 0.01$ & $1.47 \pm 0.01$ \\
\hline WHO & $5.0-9.5$ & $5.0-9.5$ & $2.0-4.0$ & $2.0-4.0$ & Nil & Nil \\
\hline
\end{tabular}

The nitrate content was minimum in DWS3 and UWS3 of the river respectively (Figure 6). The lower nitrate concentration in the water during dry season could be due to volume of water in the dry season. The maximum nitrate content was at the discharge point. The high nitrate level can be attributed to the high level of agricultural and economic activities around the area also the high level downstream and at the discharge point could be due to the impact of the cassava effluent because the effluent itself was high in nitrate. This can pose serious health hazard due to its possible conversion to highly toxic nitrate by bacteria in the intestinal tract of infants (US EPA 2004).
The sulphate concentration as shown in (Fig. 7) varied from $5.70 \pm 2.96 \mathrm{mg} / \mathrm{L}$ to $63.91 \pm 29.63 \mathrm{mg} / \mathrm{L}$ for wet season and between $4.99 \pm 0.01 \mathrm{mg} / \mathrm{L}$ and $106.77 \pm$ $6.29 \mathrm{mg} / \mathrm{L}$ in the dry season. A few studies have reported sulphate toxicity to some aquatic organisms, including some fish and aquatic mosses at concentrations at or below $100 \mathrm{mg} / \mathrm{L} \mathrm{SO}_{4}{ }^{2-}$. Bicarbonate concentration ranged between $\mathrm{ND}$ and $90.00 \pm 35.64$ for wet season and from ND to $103.20 \pm 3.39$ for dry season. It was not detected in the water sample at the discharged point. Bicarbonate regulates the acid-base balance in the body, low content in water lead to the acidification of blood and muscle. 


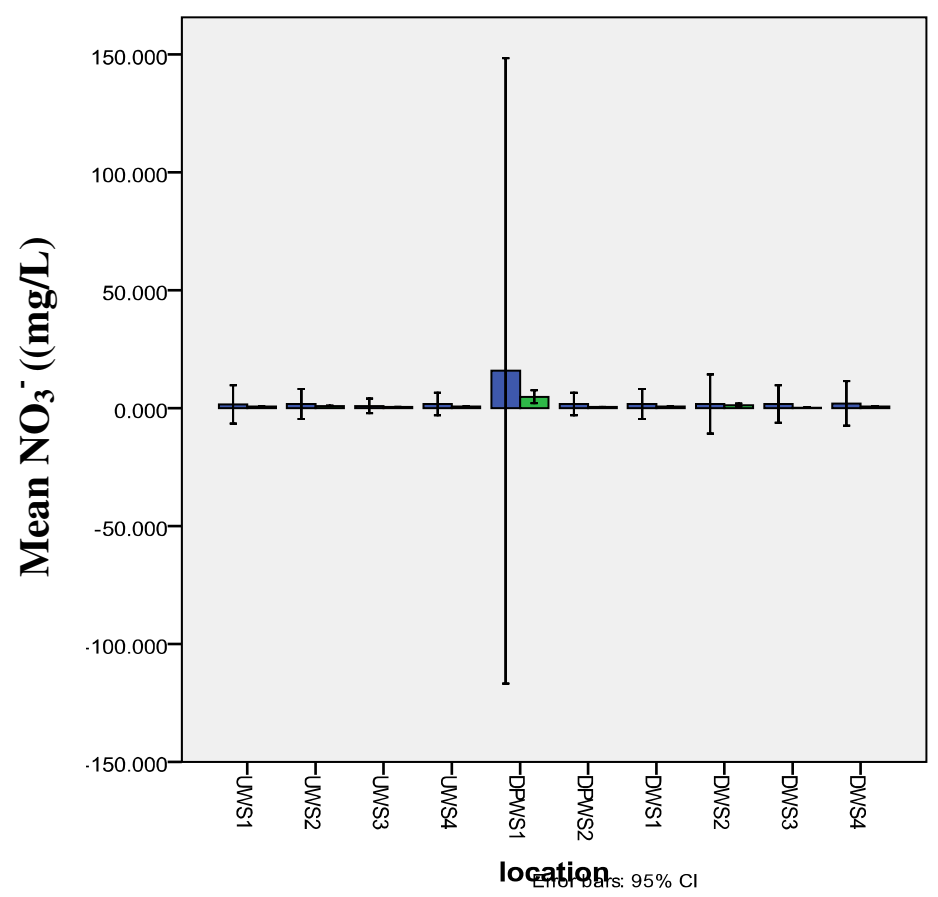

seaseon

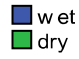

I-error bar

Figure 6: Mean seasonal variation in the nitrate ion concentration of the water samples Key: Uws - Upstream water sample, Dpws- Discharge point water sample, Dws- Downsteam Water Sample

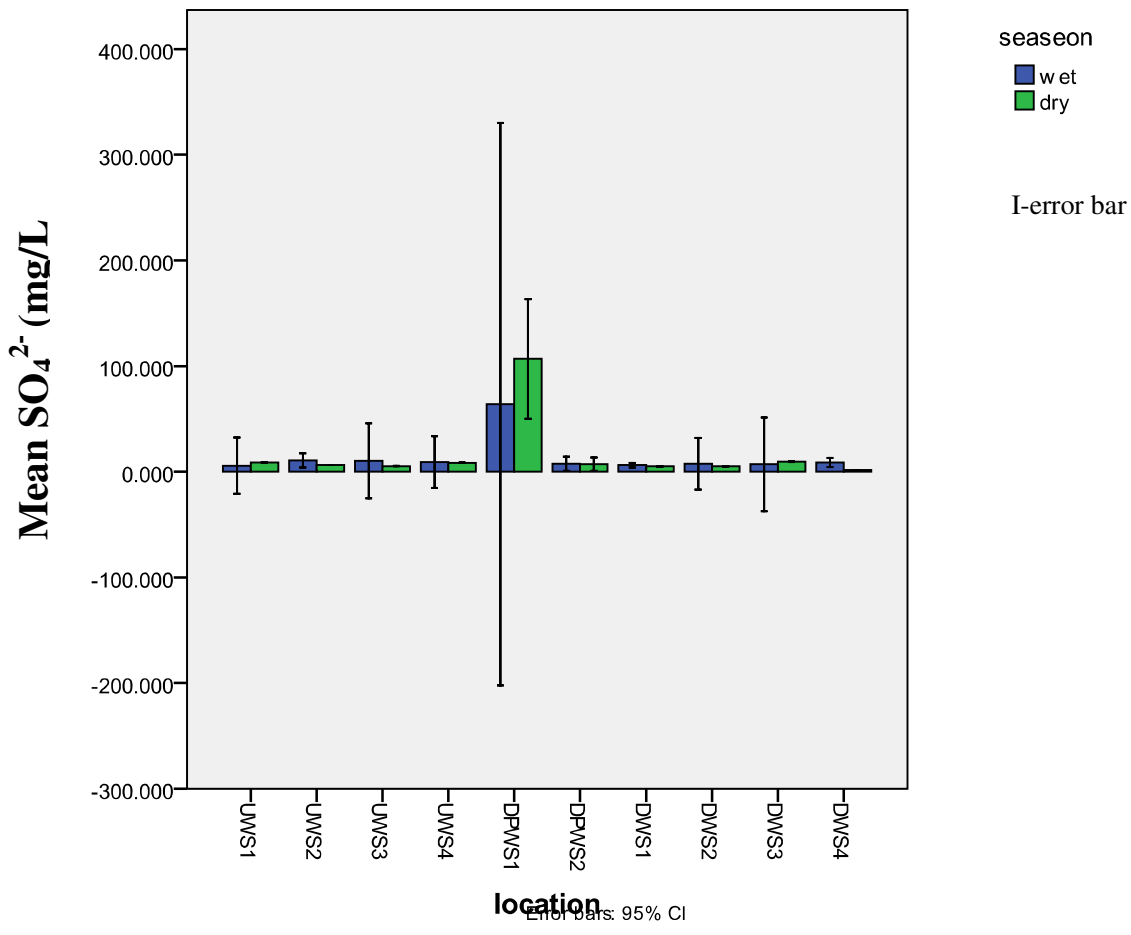

Figure 7: Mean seasonal variation in the sulphate ion concentration of the water samples. Seasonal variation in the samples

Key: Uws - Upstream water sample, Dpws- Discharge point water sample, Dws- Downsteam Water Sample 
Impact of Industrial Cassava Effluent Discharge on the Water Quality................ KOYA et al.

The ANOVA results showed the difference in the various sampling points in relation to the parameters. The result showed that there was significance difference in all the parameters at $95 \%$ confidence level at different sampling points. This implies that the effluent had an impact on the river. Also there was significance difference between the values obtained in the wet and dry season which means that season could influence the concentration of some contaminants in the water. Clearly, there was interaction between sampling location and season in some of the parameters while in others; there was no significant interaction between them. This implied that the effluent had an impact on the receiving water since they flow along the same course, particularly at the downstream.

\section{Conclusion and Recommendation}

It is concluded from the study that cassava effluent from Cassava factory had negative effect on the receiving water and as such, rendered the water unfit for human use. The pollutants have shown to be present in concentrations, above WHO limits which may be toxic to different organisms. It is therefore recommended that waste water from cassava processing factory be treated before release. Water utilization should be minimized through use of appropriate technology.

\section{Acknowledgement}

The authors are thankful to the Hydrobiology Laboratory, Department of Zoology, Obafemi Awolowo University, Ile-Ife, for providing the necessary laboratory facilities to carry out the experimental work.

\section{References}

Adakole, J.A. and Anunne, P.A. (2003). Benthic macro invertebrates as indicators of environmental pollution. Journal of Aquatic Sciences 18(2):85-92.

Adewoye, S.O. (2013). Seasonal Assessment of Impact of Industrial Effluent Discharges on the Water Quality of Asa River, Ilorin Nigeria. International Journal of Research in Environmental Science and Technology. 3(2):65-70

Adewoye, S.O., Fawole, O.O., Owolabi, O.D. and Omotosho, J.S. (2005). Toxicity of cassava waste water effluents to African catsion Clarias gariepinus (Burchell; 1822). Ethiopia Journal of Science. 28(2):190-194.

Akpan, A.W. (2004). The Water Quality of Some Tropical Freshwater Bodies in Uyo (Nigeria) Receiving Municipal Effluent, SlaughterHouse Washings and Agricultural Land Drainage. Environmentalist, 24: 49-55. http://dx.doi.org/10.1023/B:ENVR. $0000046346.93401 .5 \mathrm{c}$

American Public Health Association; (1999) Standard Methods for Examination of Water \& Wastewater 20th edition Washington, DC.

Arimoro, F.O. (2009). Impact of Rubber Effluent Discharges on the Water Quality and Macroinvertebrate Community Assemblages in a Forest Stream in Niger Delta. Chemosphere, 77: 440-449. http://dx.doi.org/10.1016/j.chemosp here.2009.06.031

Arimoro, F.O. and Ikomi, R.B. (2008). Response of Macroinvertebrate Communities to Abattoir Wastes and Other Anthropogenic Activities 
in a Municipal Stream in the Niger Delta, Nigeria. Environmentalist. 28: 85-98.

http://dx.doi.org/10.1007/s10669007-9033-8

Arimoro, F.O. and Osakwe, E.I. (2006). The influence of sawmill wood wastes on the distribution and population of macroinvertebrates at Benin River, Niger Delta Area, Nigeria. Chemistry and Biodiversity, 3:578-592.

Awoyemi, O.M. and Achudume, A.C. and Okoya, A.A. (2014). The Physicochemical Quality of Groundwater in Relation to Surface Water Pollution in Majidun Area of Ikorodu, Lagos State, Nigeria. American Journal of Water Resources, 2(5): 126-133

Claude, F. and Denis, F. (1990). African Cassava Mosaic Virus: Etiology, Epidemiology and control Plant Disease 64(6): 404-411.

Department of Fisheries and Aquatic Sciences, Institute of Food and Agricultural Sciences, University of Florida (2004). A beginner's guide to water management color, 1st Edition.

Ehiagbonare, I.J.E., Adjarhore, R.Y. and Enabulele, S.A. (2009). Effect of cassava effluent on Okada natural water African Journal of Biotechnology. 8(12): 2816-2818

Federal Environmental Protection Agency (1991). Guideline and Standard for Environmental Pollution Control in Nigeria. FG Press pp. 238

Food and Agricultural Organisation (2004). Strategic Environmental assessment. http://www.fao.org// docrep/4/17/2006.

Francis, O., Arimoro, C., Iwegbue, M.A. and Enemudo, B.O. (2008). Effects of cassava Effluent on benthic macro invertebrate assemblages in a tropical stream in southern Nigeria Acta Zoologica Lituanica, 18(2):

Jonnalagadda, S.B. and Mhere, G. (2001). Water quality of the Odzi River in the eastern highlands of Zimbabwe.Water Research 35(10):2371-2376.

Khan, S. and Noor, M. (2002). Investigation of pollutants in wastewater of Hayatabad Industrial Estate Peshawar. Pakistan Journal of Agriculture Sciences 2:457-461.

Mahananda, R., Mohanty, B.P. and Behera, N.R. (2010). PhysicoChemical Analysis of Surface And Ground Water of Bargarh Districy, Orissa, India IJRRAS 2 (3)

Manahan, S.E. (1994). Environmental Chemistry. 6th. Ed. Lewis Publisher, CRC Press Inc. USA.

Muoghalu, B.N and Omocho, V. (2000). Environmental Health Hazards Resulting from Awka Abattoir. Africa Journal of Environmental Studies, 2:72-73.

NEQS (2000). National Environmental Quality Standards for municipal and liquid industrial effluents.

Nwaugo, V.O. and Onyeagba, O.M. (2004). Effects of calcium carbide wastes on soil Nitrifying bacteria in Okigwe, Imo State Journal of Applied Science. 7:4451-4458.

Nweke, F.I., Scott, G.J., Fergusson, P.I. and Herrera, J.E (Eds.) (1992). Traditional cassava processing in Sub-Saharan Africa and research implications in Product Development for Root and Tuber Crops. Volume III - Africa. International Potato Center (CIP), Lima, Peru. pp. 147-164.

Ololade, I.A. and Ajayi, A.O. (2009). Contamination profile of major rivers along the highways in Ondo State, Nigeria Journal of Toxicology and Environmental Health Sciences, 1(3): 038-053. 
Suren, A.M. (2000). Effects of Urbanization. In: Collier K. J. Wintenbourn, M. J. (eds) New Zealand and Limnological Society. Christchurch, New Zealand. pp. 260-288.

Tariq, M., Ali, M. and Shah, Z. (2006). Characteristics of industrial effluents and their possible impacts on quality of underground water: journal of Soil \& Environment. 25(1):64-69.

Thomas, J.M., Ward, C.H., Raymond, R.L., Wilson, J.T. and Lohehr, R.C. (1992). Bioremediation. In
Encyclopedia of Microbiology I (J. Lederberg ed.) Academic Press London. pp. 369-377.

United State Environmental Protection Agency, US EPA (2004). EPA groundwater and drinking water current standards. EPA office of water, Washington DC, USA.

World Health Organization (2010). Guidelines for Drinking water Quality. Recommendation, Geneva, pp. 1-6. Retrieve from http://www.who.int/water_sanitatio n_health/WHS_WWD2010_guideli nes_2010_6_en. 